\title{
The Impact of Corporate Social Responsibility on Organizational Performance in Telecommunication Sector in Jordan
}

\author{
Bana Al-ma'ani ${ }^{1}$, Shaker Al-Qudah ${ }^{2} \&$ Husam Shrouf $^{2}$ \\ ${ }^{1}$ School of Business, The University of Jordan, Amman, Jordan \\ ${ }^{2}$ School of Business, Applied Science Private University, Amman, Jordan \\ Correspondence: Shaker Al-Qudah, School of Business, Applied Science Private University, Amman, Jordan. E- \\ mail: shakerqudah@yahoo.com
}

Received: January 25, 2019

Accepted: February 14, 2019

Online Published: March 13, 2019

doi:10.5539/mas.v13n4p1

URL: https://doi.org/10.5539/mas.v13n4p1

\begin{abstract}
The objective of the current study is to examine the impact of both internal and external CSR on both non-financial and financial performances. The population of the study represented telecommunication companies in Jordan. A survey questionnaire was prepared based on the published literature, and the data were collected from 500 repondents of the targeted companies. The necessary tests to ensure reliability and validity were performed using SPSS. The results indicated that both types of performance are positively influenced by internal CSR. External CSR showed positive influence on non-financial performance, while its effect on financial performance was insignificant and negative. The study suggests that CSR is essential factor that is expected to boost performance of Jordanian telecommunication companies. Applying CSR will result in employee and customer satisfaction and increase the levels of loyalty of internal and external stakeholders. Managers in the developing countries have to be aware of the advantages of adopting CSR in today's dynamic and competitive environment.
\end{abstract}

Keywords: Jordan, corporate social responsibility, organizational performance, telecommunication sector

\section{Introduction}

Organizations had been struggling for long time to maximize profits in several ways regardless the impact on customers and environment. Recently, different factors have forced organizations to pay a considerable attention to the concept of corporate social responsibility (CSR). Such factors include, but not limited to, pressures from customers, increased awareness concerning environmental issues, globalization, increased competitiveness, legal regulations, increasing media scrutiny, and dynamic and complex business environment (Awad et al., 2016; AlGhwayeen and Abdallah, 2018.

In such an environment, organizations have to become adept at fulfilling the aforementioned expectations. Managers attempt to comply with legal, ethical, environmental, and social requirements. This led to increased awareness of social responsibility, and many organizations started to consider this concept in their structures and processes (Thorone et al., 2013). CSR is no longer an option, but a requirement (Cone, 2013).

Though the concept of CSR became a popular term in the 1960s, it has been increasingly used among firms, authorities and in the press in the last years (Ditlev-Simonsen, 2011). Several empirical studies investigated the impact of CSR on organizational, financial, market, and employee performance. Even though the majority of previous studies reported positive associations between CSR and performance outcomes, some studies reported contrasting and conflicting results concerning the effects of internal and external Corporate Social Responsibility on financial performance and non-financial performance. Additionally, a very limited number of studies attempted to investigate this relationship in Jordan.

The importance of this research lies on its expected empirical and theoretical contribution to the literature by investigating the influence of CSR in improving performance in terms of financial and non-financial perspectives. Only a small number of studies have investigated the effects of CSR on financial and nonfinancial performance aspects implying that this area is not fully investigated. Furthermore, the expected practical contribution to Jordanian companies must not be overlooked. The findings of this study hopefully will help managers to build the proper CSR strategy in their companies. Moreover, investigating the influences of both internal and external CSR on performance is expected to shed more light on this concept in Jordan. 


\section{Literature Review}

\subsection{Corporate Social Responsibility}

Nicolau (2008) defined CSR as the profited statues and caring for CSR decision's for the stakeholders. Also, Chahal and Sharnma (2006) defined it as the firm commitments to produce and improve society and it's organizations' by utilizing different business and social actions to ensure that it provides equal and sustainable benefits for drives stakeholder. Furthermore, (Mcalaistec et al. 2003) defined CSR that it's about adoption by business of as a strategic focus to fulfill the economics, legal, morality and philanthropic social responsibilities expected by its stake and share holders. As well as, European commission (2001) defined CSR as the concept where companies integrate social and environmental categories in their interaction with their stakeholders.

\subsubsection{Internal Social Responsibility}

Internal corporate social responsibility refers to practices related to the physical and mental workplace of representatives (Turker, 2009). It is communicated in sympathy toward the wellbeing and prosperity of representatives (Wojtaszczyk, 2008), their preparation and interest in the organization (Brammer et al., 2005), fairness of chances (Newman and de Vries, 2011 Suifan et al., 2017), and work-family relationship (Suifan et al., 2018; Marchese and Bassham, 2002).

Baranco and Rodigues (2006) found, the corporate social responsibility includes many issues such as HRM, healthy and satisfying work conditions and building relationships between local comities, suppliers, and consumers. They suggested that firms should deal with any problems result from their operations independently, without being forced by the laws and government regulations.

\subsubsection{External Social Responsibility}

External social responsibility is considered as one of those business practices that have good impact on public and can be observed by customers (Calveras, 2013). In addition, external CSR refers to GSR activities steered outside an organization, such as activities directed to local community, customers, partners, suppliers, and public agencies (Albuhisi and Abdallah, 2018; Saleh et al., 2017; Al-bdour et al., 2010).

The external social responsibility may include government and policies, consumers, small suppliers, environmental and other pressure groups, trade unions, and human rights and pressure groups (Abdallah and Matsui, 2008; Abu Nimeh et al., 2018).

\subsubsection{Dimensions of External CSR}

\subsection{Environmental CSR}

Sands (2015) defined the environmental CSR as doing well toward the natural environment. Environmental social responsibility was also defined as the degree of taking in consideration on the social responsibility in the operation activity of the organization (Jyachandran et al., 2013).

The broader dimension of environmentally social responsibility, therefore, calls for innovations in production and marketing to reap the benefits of proactive social action (Suifan et al., 2016; Abdallah et al., 2009). Pollution control for example, may be perceived by some companies to be an expensive social action program as pollution control equipment (Alkhalidi and Abdallah, 2018; Nehrt, 1996). Furthermore, pollution prevention through the use of environmentally friendly technology in production and marketing can lead to resource productivity in terms of reduce cost of operation (Omar et al., 2016; Marrios, 1997).

\subsection{Customer}

Social responsibility toward the customer can appear in being transparence, and to give the full information about the service that the customer need and to give him the exact needed service (Abdallah et al., 2017).

Customer awareness of CSR actions of an organization or brand has also shown to affect purchase intentions, and purchase intentions has shown to affect customer loyalty and retention (Ali et al., 2010).

\subsection{Community}

The community dimension is incredibly important to pay attention to, but often overlooked unless a catastrophic event happens to grab the public's attention. The community dimensions are most closely linked with human and labor rights (Sands, 2015).

Community refers to those members of society who are aware, concerned, or in some way affected by the operations and output of the organization (Thorone, 2003). Social responsibility toward community can appear in a wide range of corporates endeavors, includes.adding flowers to the local parks and beautify it, various 
educational campaigns, helping poor people, buy medical machines for the cancer centers. These endeavors are oftentimes local in nature and concentrated on an issue that is currently very important in a given community (Zapotorczny, 2012)

\subsection{Performance}

Performance of organizations is defined as including financial and nonfinancial indicators, which offers information on the level of achievements and outcomes (Gavrea et al., 2011)

Performance in many studies was defined as the best view of financial performance (Cameron, 1986; Combs et al., 2005). There are lots of arguments reviewing the performance from customer satisfaction and employee satisfaction. Defining performance as the satisfaction of stakeholders (Connolly, et al., 1980; Hitt, 1988; Zammuto, 1984) helps to differentiate between antecedents and performance outcomes. In this research, non-financial and financial performances are considered. Non-financial performance consists of customer's satisfaction, employee satisfaction, and reputation.

\subsubsection{Non-Financial Performance}

\subsubsection{Reputation}

In today's business surroundings, reputation become an essential mission that companies strive to gain. Many research showed that corporate reputation can grow in to a monumental asset of the modern firms and also it adds value for firm to drive from superior financial performance or lower risk (Eqwuorwu, 2011).

Tan (2007) shows that corporates reputations are positively correlated with superior earnings quality. Also there is many research's shows that reputation influence positively in the investment of the firm (Chung et al. 1999; Brammer et al, 2004; Black et al,1999)

\subsubsection{Customer Satisfaction}

Customer satisfactions is defined as an overall evaluations based on the customer's total purchasing and consumptions experience with a goods or services over time (Anderson, et al., 2004; Fornell 1992).

Consumer satisfaction brings several benefits such as client maintenance, positive informal publicizing about the company, and expanded future client spending (Arasli et al., 2005)

In the marketing literatures, customers satisfaction has been recognized as an very important parts of the corporation strategy (Fornell et al. 2006) and a key driver of firms long-term profitability and markets values (Gruca and Rego, 2005).

\subsubsection{Employee Satisfaction}

To attain organization improvement and growth strategy, different companies usually rely on human resource. Considering the essential role of the human aspect, companies of all types are currently view human resource strategically and paying more attentions to organizations environment and satisfaction of human needs and expectations whether material or immaterial so that to be encourged and well commited to work well. (Al-Ghalbi and Manhal, 2005; Collier et al. 2007) shows that the effective delivery of corporate social and environmental responsibility initiatives is dependent on employee responsiveness.

\subsubsection{Financial Performance}

Financial performance can be characterized as the capacity of an association to make supportability with respect to budgetary in a certain time of time utilizing capital or resource, either from the lender or the shareholder himself (Meter and Carl, 1975).

\section{Research Framework and Development of Hypotheses}

\subsection{Framework of the Study}

This research is founded on the model shown in Figure 1. The model depicts the impact of CSR on nonfinancial and financial performances of Jordanian telecommunication organizations. 


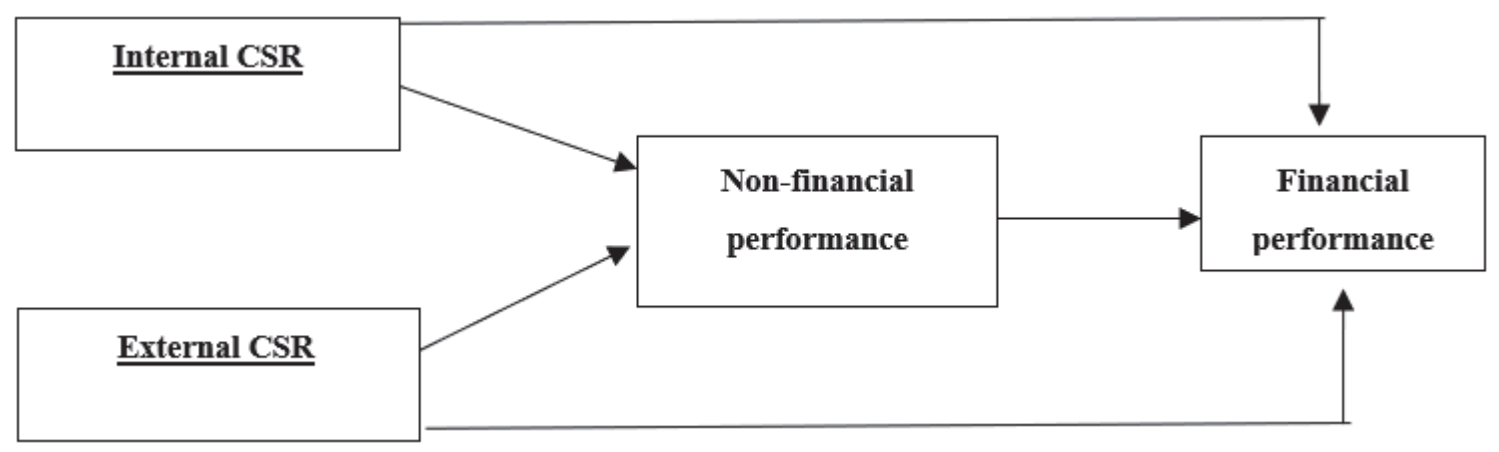

Figure 1. Research model

\subsection{Hypotheses Development}

Khan et al. (2013) found an insignificant effect of internal CSR on the satisfaction and motivation of employees. On the other hand, other researchers showed that internal CSR positively related with nonfinancial performance (e.g. Iqbal and et al., 2012; Skudine and Auruskevicience, 2010; Brammer et al., 2007; Mushtaq, 2013; James, 2004). They argued that internal CSR leads to employee's satisfaction and customer satisfaction, and as a results, organizational reputation will be enhanced.

Longo et al. (2005) classified employees-related CSR actions into different categories, the important categories is "value classes" which produces the worth for the organizations employees and therefore, induce their diverse opportunities. Employee "value classes" relate to the progresses of employees' skills, group fairnesses, in addition to physical conditions, and protection at work, wellbeing and pleasure of the employees, and value of work.

The importance of social responsibility lies on its influence on the employees within the organization to fulfill the goals and objectives that the organization is willing to achieve and it increases the quality of the products and the reputation. Also, it increases the sales and leads the organization to gain the employee's loyalty (Airan, 2006)

According to the previous studies, internal CSR toward the employees shows a strong impact on the employee satisfaction by applying the good work conditions and the authority to make decisions which will lead the employee to be motivated to work better and to be satisfied by working within the organizations that apply the CSR practices.

H1: Internal CSR positively will affect non-financial performance.

Several previous studies investigated the relationships between external CSR and bob-financial performance. For instance, Al-Ghalbi and Manhal, (2005); Collier et al. (2007); Khan et al. (2014) show that external CSR positively improves employee's attitude, and employee's attention and behaviors contribute to corporation achievements. Therefore the external CSR makes the employees feel proud of working within the organization which leads them to be satisfied. (Ekwwueme, 2013) shows that the environmental CSR practices don't affect the economic side only; it also affects the employee's satisfaction and values. In an explanation, the bottom line is expected to show how the CSR has contributed to the sustainability of the environment. Jyach et al. (2013) showed that there is a positive impact of environmental social performance on the firm performance.

Numerous studies show the relationship between external CSR and employee's satisfaction. Ali et al. (2010) found that there is a positive relationship between CSR actions and employee's organizational commitment and organizational performance by measuring 371 surveys in Pakistan. Khan et al. (2013) founded that there is a good and positive relationship between external Corporate Social Responsibility and employee's motivation and satisfaction. The following hypothesis is proposed:

H2: External CSR positively will affect non-financial performance.

CSR practices expand the benefits on the long run to exceed non-financial benefits to financial benefits. Previous studies demonstrated the connection between CSR and financial performance and reported mix results. One stream of research showed a negative influence of CSR on financial performance (e.g. Barnett and Salomon, 2012; Kang et al., 2010; Wright and Ferris, 1997). Another stream of research found positive influence of CSR on financial performance (e.g. Pirsch et al., 2007; Orlitzky et al., 2003). A third stream of researchers found no exact relationship between CSR and financial performance (Kang et al., 2010; Patten, 1991; McWilliams and Siegel, 2000). 
Most previous studies showed positive effects of internal CSR on financial performance (e.g. Simpson and Kohers, 2002; Graves and Waddock,1994; Mcgunirie et al., 1988). Nonetheless, some researchers found that internal CSR was not significantly related to financial performance (e.g. Mawangi and jerotich, 2013).

The same situation applies to the external CSR and financial performance relationship. (Enhahora et al. 2013) found a positive relationship between external CSR and financial. (Choi et al. 2010) investigate the relationship between Corporate Social Responsibility and financial performance in Korea and reported a positive relationship. On the other hand, (Babaloa, 2012) concluded that external CSR is negatively related to financial performance.

The above review demonstrates the contradicting results reported in the existing literatures. Based on the main stream of previous studies, we propose that CSR is expected to positively affect financial performance:

H3: Internal CSR positively will affect financial performance.

H4: External CSR positively will affect financial performance.

\section{Methodology}

\subsection{Data Collection}

The current study's population included all Jordanian mobile telecommunication companies. There are three telecommunication companies in Jordan: Orange, Umniah, and Zain. The telecommunication sector includes about 7000 employees. The representative sample for the current population is 364 (Sekaran and Bougie, 2010). To attain the needed sample size, 500 questionnaires were circulated. Data was collected through a web-based survey. The link to the online survey was distributed via e-mail to the employees working in the mobile companies who were randomly selected and agreed to participate. The random selection of the employees was coordinated by one human resource officer in each company. A total of 408 valid questionnaires were returned exceeding, thus, our target of 364 respondents. The response rate represented $81.6 \%$ of the targeted respondents. This response rate exceeds most of the rates reported by other studies in Jordan (e.g. Obeidat et al., 2017; Abdallah and Nabass, 2018; Yaseen et al., 2018). The potential explanation of our high response rate is that the data collection process was arranged by the human resource department which facilitated the access to the employees and encouraged them to participate.

The Jordanian Telecommunication Industry has been growing during the last years. In addition, the Jordanian market is regarded among the most attractive and potential markets in the region. In particular, it is ranked in terms of competitiveness as the second in the Middle East after the Saudi market (Khreisha, 2015). The nummer of mobile telecommunication companies in Jordan is three, namely, Zain, Uminah, and Orange. A report prepared by Arab Advisors Group shows that the lagerst market share is occupied by Zain Jordan and represents $40 \%$. Orange Jordan has a market share of $31 \%$, and Umnia Jordan has a market share of $29 \%$.

\subsection{Measures}

The measurement scales for this study were adopted from adapted from Skudiene and Auruskeviciene (2012), Chung et al. (2015). The original questionnaires developed in English, then was translated by authors from Arabic back to English. Then, the questionnaires was tested by seven professors in business schools in order to assess its appropriateness in terms of the phrasing of questions, the complexity of language, response scale, and redundancy of questions. This procedure was used to ensure that the questionnaire was well designed and that the items measured the relevant dimensions. Based on this review, the questionnaire was corrected accordingly.

The validity of the study's scales was evaluated using exploratory and confirmatory factor analyses. To ensure sampling adequacy for factor analysis, Kaiser-Meyer-Olkin (KMO) test was performed (Hair et al., 2010). Also, Bartlett's test of sphericity to test for homogeneity of variances was carried out. The output indicated that KMO value for the scales exceeded 0.50 and Bartlett's test of sphericity values were statistically significant $(\mathrm{p}<0.05)$ indicating the suitability of factor analysis.

First, we applied EFA with principal component analysis and pro max rotation method. EFA was applied for CSR with all question items entered together, and for performance items in a similar manner. The pattern matrix showed four distinct factors related to CSR and four factors related to performance. Question items that showed loadings below 0.40 were deleted. All the retained questions loaded onto their respective factors with factor loadings greater than 0.40. Additionally, Eigen values for all the eight scales exceeded 1.0.

To evaluate reliability of the constructs, Cronbach's $\alpha$-coefficient was used. In general, usually in business management research Cronbach's $\alpha \geq 0.70$ is preferred (Hair et al., 2010). All the constructs met the recommended value of $\alpha \geq 0.70$ as shown in Table 1 indicate that the constructs are valid and internally consistent.

In addition, confirmatory factor analysis was used for CSR constructs using Amos 20. Factor loadings of some 
question items were below the recommended minimum of 0.50 and were deleted. The fit indices for the proposed model with constructs representing the first order were within acceptable levels (X2 = 195.669; d.f. $=69 ;$ X2/d.f. $=2.83 ; \mathrm{CFI}=0.930 ; \mathrm{GFI}=0.925 ; \mathrm{NNFI}=0.908 ; \mathrm{NFI}=0.904 ; \mathrm{RMSEA}=0.075$ and $\mathrm{RMR}=0.062)$. The normed chi-square of 2.83 was lower than the highest recommended number of 3.0 (Bollen, 1989; Al-Sa'di et al., 2017). Comparative fit index (CFI), goodness-of-fit index (GFI), non-normed fit index (NNFI), and normed-fit index (NFI) were all above the lowest accepted ratio of 0.90 (Garver and Mentzer, 1999). These values provided support for uni dimensionality and convergent validity. Besides, the beta coefficients (standardized) for all the questions were above than the double of their standard errors, providing supplementary evidence of convergent validity (Anderson and Gerbing, 1988). Also, the loadings of all the factors exceeded 0.50. Besides, the values of average variance extracted (AVE) for the study's scales were above 0.50 adding more support for convergent validity (Fornell and Larcker, 1981; Ayoub et al., 2017).

In addion, the fit indices for the model with the constructs of the second order of external CSR dimensions (customer, society, and environmental) showed acceptable levels $(\mathrm{X} 2=196.025$; d.f. $=67$; X2/d.f. $=2.910$; CFI $=$ $0.921 ; \quad \mathrm{GFI}=0.923 ; \mathrm{NNFI}=0.895 ; \mathrm{NFI}=0.897 ; \mathrm{RMSEA}=0.081$ and $\mathrm{RMR}=0.078)$. It should be noted that NNFI and NFI indices were very a little lower than the proposed minimum ratio of 0.90 (Garver and Mentzer, 1999; Abdallah et al., 2017).

Similarly, CFA was performed for first order constructs of performance. Some question items were removed because their loadings were below 0.50 or to enhance model fit indices. The fit indices of the last model with first order scales shwed acceptable levels $(\mathrm{X} 2=111.555 ;$ d.f. $=38 ; \mathrm{X} 2 /$ d.f. $=2.935 ; \mathrm{CFI}=0.958 ; \quad \mathrm{GFI}=0.950 ; \mathrm{NNFI}$ $=0.939 ; \mathrm{NFI}=0.938 ; \mathrm{RMSEA}=0.069$ and $\mathrm{RMR}=0.055)$. Tables 1 and 2 present reliability and validity results for the study constructs.

Table 1. validity and Reliability of the CSR scales

\begin{tabular}{|c|c|c|c|c|c|}
\hline Scale & $\begin{array}{l}\text { Question } \\
\text { number }\end{array}$ & $\begin{array}{c}\text { Coefficients } \\
\text { EFA }\end{array}$ & $\begin{array}{c}\text { Coefficients } \\
\text { CFA }\end{array}$ & $\begin{array}{c}\text { Cronbach's } \\
\text { alpha }\end{array}$ & $\begin{array}{l}\text { Composite } \\
\text { reliability }\end{array}$ \\
\hline \multirow[t]{3}{*}{ Internal CSR } & Q4 & .760 & .716 & 0.777 & 0.786 \\
\hline & Q5 & .892 & .686 & & \\
\hline & Q6 & .853 & .820 & & \\
\hline \multirow{3}{*}{$\begin{array}{l}\text { External } \\
\text { (customer) }\end{array}$} & Q9 & .761 & .608 & 0.720 & 0.724 \\
\hline & Q10 & .824 & .679 & & \\
\hline & Q11 & .787 & .757 & & \\
\hline \multirow[t]{3}{*}{ External CSR (society) } & Q14 & .865 & .644 & 0.797 & 0.822 \\
\hline & Q15 & .899 & .975 & & \\
\hline & Q16 & .729 & .691 & & \\
\hline \multirow{4}{*}{$\begin{array}{l}\text { External } \\
\text { (environment) }\end{array}$} & IC2 & 0.941 & 0.743 & 0.856 & 0.855 \\
\hline & Q20 & .882 & .772 & & \\
\hline & Q21 & .900 & .879 & & \\
\hline & Q22 & .862 & .788 & & \\
\hline \multirow[t]{3}{*}{ External CSR ${ }^{\mathrm{a}}$} & Customer $^{\mathrm{b}}$ & 0.687 & 0.615 & 0.712 & 0.727 \\
\hline & Society ${ }^{b}$ & 0.754 & 0.684 & & \\
\hline & $\begin{array}{c}\text { Environme } \\
\text { ntal }^{\mathrm{b}}\end{array}$ & 0.763 & 0.690 & & \\
\hline
\end{tabular}

aSecond order factors; ${ }^{\mathrm{b} S e c o n d}$ order indicators. 
Table 2. Reliability and validity of the performance constructs

\begin{tabular}{lccccc}
\hline Scale & $\begin{array}{c}\text { Question } \\
\text { number }\end{array}$ & $\begin{array}{c}\text { Coefficients } \\
\text { EFA }\end{array}$ & $\begin{array}{c}\text { Coefficients } \\
\text { CFA }\end{array}$ & $\begin{array}{c}\text { Cronbach's } \\
\text { alpha }\end{array}$ & $\begin{array}{c}\text { Composite } \\
\text { reliability }\end{array}$ \\
\hline Employee satisfaction & Q23 & .864 & .735 & 0.769 & 0.776 \\
& Q24 & .838 & .819 & & \\
& Q25 & .783 & .637 & & \\
Reputation & Q28 & .824 & .754 & 0.788 & 0.789 \\
& Q29 & .939 & .703 & & \\
Q30 & .692 & .776 & & \\
Fustomer satisfaction & Q33 & .780 & .819 & 0.764 & 0.754 \\
& Q34 & .971 & .736 & & \\
& Q37 & .735 & .771 & 0.817 & 0.822 \\
& Q38 & .896 & .853 & & \\
\hline
\end{tabular}

\section{Results}

The hypotheses of the current study were examined by using structural equation modeling with Amos. The results revealed a significant and positive influence of internal CSR $(\beta=0.245, \mathrm{p}<0.001)$ and external CSR $(\beta=0.253$, $\mathrm{p}<0.001$ ) on non-financial performance; Thus, hypotheses H1 and H2 are supported.

Results also showed that the effects of internal CSR on financial performance was positive and significant $(\beta=$ $0.222, p=0.010)$. However, the effect of external CSR on financial performance was negative and not significant $(\beta=-0.035, p>0.05)$; hypothesis H3 is supported while hypothesis H4 is not supported.

Figure 2 shows direct impacts and Table 3 summarizes the results of the study's hypotheses.

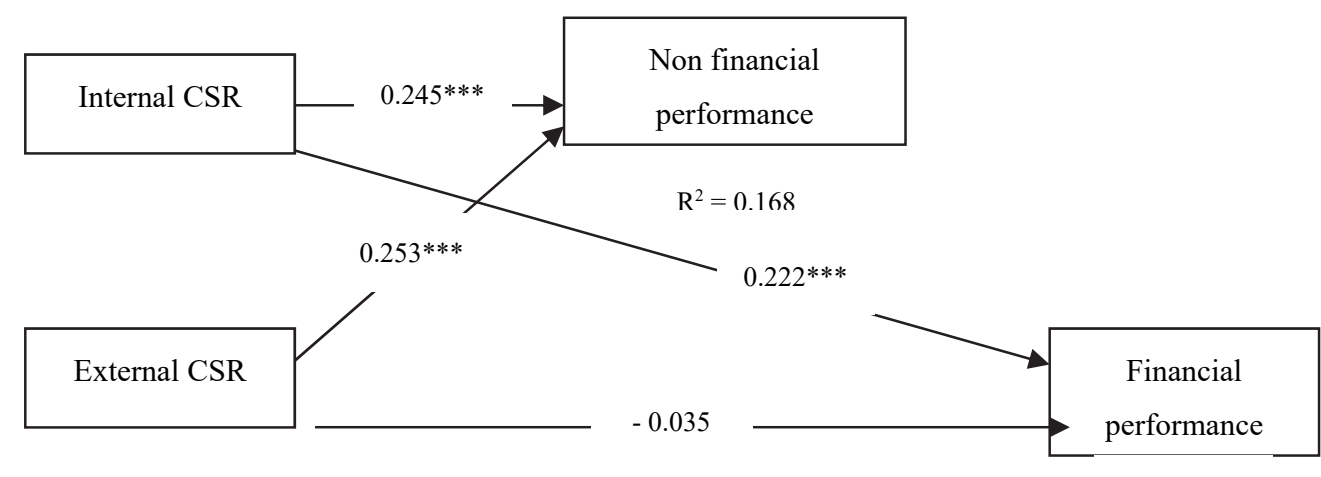

Note: $* * *: \mathrm{p}<0.001$

$$
\mathrm{R}^{2}=0.242
$$

Figure 2. Internal and external CSR - non-financial performance - financial performance model

Table 3. Results Summary

\begin{tabular}{|c|c|c|c|}
\hline Hypothesis & Path & Standardized effect & Result \\
\hline H1 & $\mathrm{ICSR} \rightarrow \mathrm{NFP}$ & $0.245^{* * *}$ & Supported \\
\hline $\mathrm{H} 2$ & $\mathrm{ECSR} \rightarrow \mathrm{NFP}$ & $0.253 * * *$ & Supported \\
\hline H3 & $\mathrm{ICSR} \rightarrow \mathrm{FP}$ & $0.222 * * *$ & Supported \\
\hline$\overline{\mathrm{H} 4}$ & $\overline{\mathrm{ECSR}} \rightarrow \mathrm{FP}$ & -0.035 & Rejected \\
\hline
\end{tabular}

\section{Discussion and Conclusion}

\subsection{Discussion of Findings}

The results showed that internal CSR affected both financial and non-financial performance implying that adopting 
CSR practices leads to increased productivity, higher employee satisfaction, reduced operating costs, and increased reputation. Brammer, et al. (2007) examined the relationship between organization commitment and employees perceptions of Corporate Social Responibility based on the theoretical foundations of social identity theory. They found that perceptions of CSR were positively correlated with employee commitment.

The results indicated that external CSR positively affected non- financial performance, while the effects on financial performance were negative and not significant. Results consistent with the findings of Skudiene and Auruskeviciene (2012) who concluded that external CSR increases motivation of employees. Furthermore, organizational culture that emphasizes external CSR will influence employee's behavior and work performance. The findings are also in line with Hancock (2005) who asserted that companies should promote external CSR culture to earn internal support and a good reputation from their employees as well as customers. Additionally, the results consist with the results of Egan (2006) who found that external CSR activities related to ethical practices had improved the commitment of employees. The potential justification is that by applying external social responsibility employees are more likely to become more satisfied. Employees also will be more proud to work for such organization whose values are directed towards long-term objectives and sustainable business and society development. Thus, the current outcome of this research, which confirms the significant association between internal CSR and financial performance, additionally, both internal and external CSR help improving employee relations and commitment to work (Backhaus, 2002). Furthermore, companies applying external CSR will be able to attract many new customers who will shift from competitors that do not apply external CSR. The new shifted customers may increase organizational financial performance through the non-financial performance. Those new customers might be willing to pay higher prices for the services provided by reputable companies that adopt external CSR (Marsteller, 2010).

\subsection{Conclusions}

The study contributes to the investigation of the effect of internal and external CSR on non-financial and financial performance. Based on the results, the following conclusions are derived:

First, internal CSR positively affects non-financial performance. The study pointed to the important role of internal CSR to improve external non-financial performance of customer satisfaction and organizational reputation.

Second, external CSR positively affect non-financial performance. The results show that external CSR have higher effect on non-financial performance than internal CSR.

Third, internal CSR positively affect financial performance. As opposite to a dominant belief among many Jordanian companies that internal CSR will reduce financial performance, this study suggests a contrary view. Committed and motivated employees are expected to be more productive, more directed towards finding opportunities for cost reduction, and more willing to retain their jobs. Despite the initial cost incurred as a result of applying internal CSR, the long-term result is improved financial performance.

Fourth, external CSR negatively and insignificantly affect financial performance. While it improves the satisfaction of employees and customers, company's reputation, and overall image, no evidence was found that it will directly affect financial performance.

\subsection{Limitations and Future Research}

The study has a number of limitations. First, through reviewing the literature, rare studies were found that developed a validated instrument to characterize the CSR. Second, to the researcher's knowledge, no studies were found that address CSR characterization and measurement in Jordanian Telecom sector.

In future, research studies are needed to enhance the result of the current study and increase the generalize ability of the results. Future studies are needed in Jordan in other industries such as manufacturing companies and other service sectors to investigate the effect of CSR on performance. Also, a future study is needed to investigate the effects of internal and external CSR on employee and customer retention rates. Moreover, future studies are needed to investigate CSR in public organizations as such studies do not exist in Jordan to the best of the researcher's knowledge. Lastly, measurement scales have usually a great effect on the results of any empirical study. Additional studies recommended with other constructs to confirm the results obtained from the current study.

\section{References}

Abdallah, A. B., \& Nabass, I. H. (2018). Supply chain antecedents of agile manufacturing in a developing country context: An empirical investigation. Journal of Manufacturing Technology Management, 29(6), 1042-1064.

Abdallah, A. B., Obeidat, B. Y., Aqqad, N. O., Al Janini, M. N., \& Dahiyat, S. E. (2017). An integrated model of job involvement, job satisfaction and organizational commitment: a structural analysis in Jordan's banking 
sector. Communications and Network, 9(1), 28-53.

Abdallah, A. B., Phan, A. C., \& Matsui, Y. (2009). Investigating the relationship between strategic manufacturing goals and mass customization. The 16th International Annual European Operations Management Association (EurOMA) Proceedings, Goteborg, June, 1-10.

Abdallah, A., \& Matsui, Y. (2008). Customer involvement, modularization of products, and mass customization: their relationship and impact on value to customer and competitiveness. The Third World Conference on Production and Operations Management Proceedings, Tokyo, August, 1-19.

Abdallah, A.B., Abdullah, M. I., \& Saleh, F. I. M. (2017). The effect of trust with suppliers on hospital supply chain performance: the mediating role of supplier integration. Benchmarking: An International Journal, 24(3), 694-715.

Abu Nimeh, H., Abdallah, A. B., \& Sweis, R. (2018). Lean supply chain management practices and performance: Empirical evidence from manufacturing companies. International Journal of Supply Chain Management, 7(1), $1-15$.

Airan, R. (2006). Social responsibility in organizations: between the responsibility of countries and the voluntary work. The Arabic journal for management, 11(3).

Albuhisi, A. M., \& Abdallah, A. B. (2018). The impact of soft TQM on financial performance: the mediating roles of non-financial balanced scorecard perspectives. International Journal of Quality \& Reliability Management, 35(7), 1360-1379.

Al-Galbi, T. (2005). Social Responsibility and Business ethics, (2nd ed), Dar Wael for publication, Amman, Jordan.

Al-Ghwayeen, W. S., \& Abdallah, A. B. (2018). Green supply chain management and export performance: The mediating role of environmental performance. Journal of Manufacturing Technology Management, 29(7), 1233-1252.

Ali, I., Rehman, K., Ali, S. Yousaf, J., \& Zia, M. (2010). Corporate social responsibility influences, employee commitment and organizational performance. African Journal of Business Management, 4, 2796-2801.

Alkhalidi, A. B., \& Abdallah, A. B. (2018). Lean bundles and performance outcomes in the pharmaceutical industry: Benchmarking a Jordanian company and Operational Excellence International Project. Modern Applied Science, 12(8), 90-102.

Al-Sa'di, A. F., Abdallah, A. B., \& Dahiyat, S. E. (2017). The mediating role of product and process innovations on the relationship between knowledge management and operational performance in manufacturing companies in Jordan. Business Process Management Journal, 23(2), 349-376.

Anderson, J. C., \& Gerbing, D. W. (1988). Structural equation modeling in practice: a review and recommended two-step approach. Psychological Bulletin, 103(2), 411-423.

Arasli, H., Salime, S., \& Salih, T (2005),Customer service quality in the Greek Cypriot banking industry. Emerald, 15(1), 41-56.

Armstrong, J. S., \& Overton, T. S. (1977). Estimating Nonresponse Bias in Mail Surveys. Journal of Marketing Research, (14), 396 - 402.

Awad, H., Al-Zu'bi, Z. M. F., \& Abdallah, A. B. (2016). A quantitative analysis of the causes of drug shortages in Jordan: a supply chain perspective. International Business Research, 9(6), 53-63.

Ayoub, H. F., Abdallah, A. B., \& Suifan, T. S. (2017). The effect of supply chain integration on technical innovation in Jordan: the mediating role of knowledge management. Benchmarking: An International Journal, 24(3), 594-616.

Babalola, Y. (2012). The impact of corporate social responsibility on firms' profitability in Nigeria. European Journal of Economics, Finance and administrative sciences, 45, 39-50.

Baron, R., \& Kenny, D. (1986). The moderator-mediator variable distinction in social psychological research: conceptual, strategic, and statistical considerations. Journal of Personality and Social Psychology, 51(6), $1173-1182$.

Bollen, K. A. (1989). Structural Equations with Latent Variables, New York: John Wiley \& Sons, Inc.

Brammer, S., Brooks, C., \& Pavelin, S. (2004). Corporate Reputation and Stock Returns: Are Good Firms Good for Investors (Electronic version). Social Science Research Network (SSRN). 
Brammer, S., Millington, A., \& Rayton, B. (2007). The contribution of corporate social responsibility to organizational commitment. International Journal of Human Resource Management, 18(10), 1701- 1719.

Chahal and Sharma (2006). Implications of Corporate Social Responsibility on marketing performance :A conceptual frame work. Journal of services Research.

Chung. K., Yu. J., \& Choi. MShin. J. et al. (2015). The Effects of CSR on Customer Satisfaction and Loyalty in China: The Moderating Role of Corporate Image. Journal of Economics Business and Management, 3(5), May 2015.

Combs, J. G., Crook, T. R., \& Shook, C. L. (2005). The dimension of organizational performance and its implications for strategic management research. In D. J. Ketchen \& D. D. Bergh (Eds.), Research methodology in strategy and management (pp. 259-286). San Diego: Elsevier.

Egan, J. (2006). Doing the decent thing: CSR and ethics in employment. IRS Employment Review, (858), 9-16. Retrieved from Business Source Premier database.

Ekwueme, C., \& Egbunike, C, O. (2013). Benefits of Triple Bottom Line Disclosures on Corporate Performance: An Exploratory Study of Corporate Stakeholders. Journal of Management and Sustainability, 3(2), 79-91.

Eqwunowu, R. (2011). Corporate Reputation and firm performance: empirical literature review evidence. International journal of business and management, 6(4).

Fornell, C., \& Larcker, D. F. (1981). Structural equation models with unobservable variables and measurement error. Journal of Marketing Research, 1(1), 39-50.

García, M., Crespo, A., \& Bosque, I. (2005). Influence of corporate social responsibility on loyalty and valuation of services. Journal of Business Ethics, 61(4), 369-385.

Garver, M. S., \& Mentzer, J. T. (1999). Logistics research methods: employing structural equation modelling to test for construct validity. Journal of Business Logistics, 20(1), 33-57.

Gavrea, C., \& 1lies, L. (2011). Determinants of organizational performance: The case of Romania. Management \& Marketing, 6(2), 285-300.

Hair, J., Black, W., Babin, B., \& Anderson, R. (2010). Multivariate Data Analysis, Prentice Hall, Inc., Upper Saddle River, NJ.

Hancock, J. (2005). Investing in Corporate Social Responsibility: A Guide to Best Practice, Business Planning \& the UK's Leading Companies, Kogan Page, London.

Harman, H. H. (1976). Modern Factor Analysis, University of Chicago Press, Chicago, USA.

Hayes, A. F. (2013). Introduction to mediation, moderation, and conditional process analysis, The Guilford Press, New York.

Hayes, A. (2009). Beyond Baron and Kenny: Statistical mediation analysis in the new millennium. Communication Monographs, 76(4), 408-420.

Hitt, M., \& Hoskiission. (1988). A Mid-Range Theory of the Interactive Effects of International and Product Diversification on Innovation and Performance. Journal of Management.

Hu, L., \& Bentler, P. M. (1999). Cutoff criteria for fit indices in covariance structure analysis: conventional criteria versus new alternatives. Structural Equation Modeling, 6(1), 1-55.

Jyachandran, M. (2013). Syringic acid, a novel natural phenolic acid, normalizes hyperglycemia with special reference to glycoprotein components in experimental diabetic rats. Journal of Acute Disease, 2, 4.

Khan, S. J., Bajpai, A., Alam, M. A., Gupta, R. P., Harsh, S., ... Sinha, P. (2013). Epithelial neoplasia in Drosophila entails switch to primitive cell states. Proc. Natl. Acad. Sci. U.S.A., 110(24), E2163--E2172.

Khreisha, D. (2015). Competition Levels in Arab Cellular Markets 2015. Arab advisors Group. Retrieved from www. Arabadvisors.com.

Kotler, P., \& Lee, N. (2005). Corporate Social Responsibility: Doing the Most Good for Your Company and Your Cause. Hoboken, N.J: Wiley, 37.

Longo, M., Mura, M., \& Bonoli, A. (2005). Corporate social responsibility and corporate performance: The case of Italian SMEs. Corporate Governance, 5, 28-42.

MacKinnon, D. (2008). Introduction to Statistical Mediation Analysis. New York: Lawrence Erlbaum. 
Mallinckrodt, B., Abraham, T., Wei, M., \& Russell, D. (2006). Advance in testing statistical significance of mediation effects. Journal of Counseling Psychology, 53(3), 372-378.

Marstellers, B. (2010). Corporate social responsibility branding survey, peen skhoon Berland.

Nehrt, C. (1996), Timing and intensity of environmental investments. Strategic Management Journal, 17(7), 535547.

Obeidat, B. Y., Abdallah, A. B., Aqqad, N. O., Akhoershiedah, A., \& Maqableh, M. (2017). The effect of intellectual capital on organizational performance: the mediating role of knowledge sharing. Communications and Network, 9(1), 1-27.

Omar, B., Hiyassat, M., Sweis, G., Abdallah, A., Saleh, R., \& Sweis, R. (2016). Evaluation of green building awareness in the construction industry: the case of Jordan. Interdisciplinary Environmental Review, 17(3/4), 209-231.

Orlizky, M., Schmidt, F., \& Rynes, S. (2003). Corporat social and financial performance, a mata-analysis. Organizational study, 24, 8.

Pirsch, J., Gupta, S., \& Grau, S. L. (2007). A framework for understanding corporate social responsibility programs as a continuum: An exploratory study. Journal of Business Ethics, 70, 125-140.

Saleh, F. I. M., Sweis, R. J., Abdelqader, B. Y., Abdallah, A. B., \& Arafeh, M. (2017). The effect of TQM dimensions on the performance of international non-governmental organisations operating in Jordan. International Journal of Productivity and Quality Management, 21(4), 443-459.

Sands. (2015). Corporate Social Responsibility, Sands for Singapore.

Shehadeh, R. M., Al-Zu'bi, Z., Abdallah, A. B., \& Maqableh, M. (2016). Investigating critical factors affecting the operational excellence of service firms in Jordan. Journal of Management Research, (1), 18-49.

Shrout, P., \& Bloger, N. (2002). Mediation in experimental and nonexperimental studies: new procedures and recommendations. Psychological Methods, (4), 422-445.

Skudiene, V., \& Auruskeviciene, V. (2012). The contribution of corporate social responsibility to internal employee motivation. Baltic Journal of Management, 7(1), 49-67.

Suifan, T. S., Abdallah, A. B., \& Al Janini, M. (2018). The impact of transformational leadership on employees' creativity: The mediating role of perceived organizational support. Management Research Review, 41(1), 113132.

Suifan, T. S., Abdallah, A. B., \& Diab, H. (2016). The influence of work life balance on turnover intention in private hospitals: The mediating role of work life conflict. European Journal of Business and Management, 8(20), 126-139.

Suifan, T. S., Diab, H., \& Abdallah, A. B. (2017). Does organizational justice affect turnover-intention in a developing country? The mediating role of job satisfaction and organizational commitment. Journal of Management Development, 36(9), 1137-1148.

Thorone, F. (2003). Business and society. USA: Houghton Mifflin.

Yaseen, M. M., Sweis, R. J., Abdallah, A. B., Obeidat, B. Y., \& Sweis, N. (2018). Benchmarking of TQM practices in the Jordanian pharmaceutical industry (a comparative study). Benchmarking: An International Journal, 25(9), 4058-4083.

Zapotozny, K. (2012). Analysis of corporate responsibility foundation theories: strategic perspectives for doing good, a dissertation submitted to the faculty of the Chicago school of professional psychology in practical fulfillment of the requirements for the degree of doctor of psychology.

\section{Copyrights}

Copyright for this article is retained by the author(s), with first publication rights granted to the journal.

This is an open-access article distributed under the terms and conditions of the Creative Commons Attribution license (http://creativecommons.org/licenses/by/4.0/). 